FROM WATER TO WINE 



\title{
FROM WATER TO WINE
}

\section{Becoming Middle Class in Angola}

\author{
JESS AUERBACH
}

Teaching Culture: UTP Ethnographies for the Classroom

\section{UNIVERSITY OF TORONTO PRESS}

Toronto Buffalo London 
(C) University of Toronto Press 2020

Toronto Buffalo London

utorontopress.com

Printed in Canada

ISBN 978-1-4875-0641-4 (cloth)

ISBN 978-1-4875-3411-0 (EPUB)

ISBN 978-1-4875-2433-3 (paper)

ISBN 978-1-4875-3410-3 (PDF)

All rights reserved. The use of any part of this publication reproduced, transmitted in any form or by any means, electronic, mechanical, photocopying, recording, or otherwise, or stored in a retrieval system, without prior written consent of the publisher-or in the case of photocopying, a licence from Access Copyright, the Canadian Copyright Licensing Agency-is an infringement of the copyright law.

\section{Library and Archives Canada Cataloguing in Publication}

Title: From water to wine : becoming middle class in Angola / Jess Auerbach.

Names: Auerbach, Jess, author.

Series: Teaching culture.

Description: Series statement: Teaching culture : UTP ethnographies for the classroom | Includes bibliographical references and index.

Identifiers: Canadiana (print) 20190206039 | Canadiana (ebook) 2019020608X

| ISBN 9781487506414 (cloth) | ISBN 9781487524333 (paper) | ISBN 9781487534110

(EPUB) | ISBN 9781487534103 (PDF)

Subjects: LCSH: Middle class-Angola. | LCSH: Angola-Social life and customs 21st century.

Classification: LCC HT690.A54 A94 2020 | DDC 305.5/509673-dc23

We welcome comments and suggestions regarding any aspect of our publicationsplease feel free to contact us at news@utorontopress.com or visit us at utorontopress.com.

Every effort has been made to contact copyright holders; in the event of an error or omission, please notify the publisher.

University of Toronto Press acknowledges the financial assistance to its publishing program of the Canada Council for the Arts and the Ontario Arts Council, an agency of the Government of Ontario.

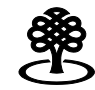

Canada Council for the Arts Funded by the
Government of Canada
Financé par le gouvernement du Canada

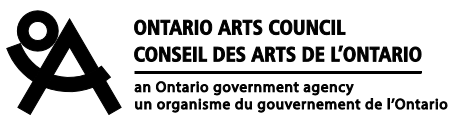

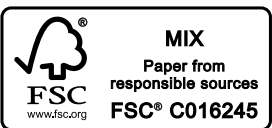


To the memory of my grandfather, Franz, who set the direction; to my parents, Christina and Raymond, who raised me, hugged me, and let me go;

and to Aarvin Jahajeeah, for bringing me home. 
